\title{
Single ventilator for multiple patients?
}

\section{¿Un solo ventilador para varios pacientes?}

\section{José L. Sandoval-Gutiérrez}

Instituto Nacional de Enfermedades Respiratorias "Ismael Cosío Villegas", Diagnostic Auxiliary Services Sub-directorate, Mexico City, Mexico

Dr. Castañón González et al. published an interesting article about the therapeutic possibility of simultaneous mechanical ventilation: ${ }^{1}$ they describe an experimental work by means of which they identified that there were no significant statistical differences in different ventilation parameters.

This scenario was thought of due to the deficit of ventilators in the face of the COVID-19 pandemic. Contrary to the recommendation in this regard, some specialists considered that this option might be necessary, although it constituted an extreme measure. So far, we do not know if any center has implemented it; probably not, because of the ethical and bioethical connotations it entails.

Connecting two or more patients with respiratory distress syndrome, different respiratory mechanics, and severity baseline states to a single ventilator would complicate case management and follow-up. Even when circuits have filters, infection control would not be optimal. If the intention is thanatological, this purpose could be considered, but, of course, it would not be a therapeutic measure.

Although popular wisdom says that "where two can eat, three can eat as well", it still cannot be claimed that "where one can be ventilated, two can be ventilated as well".

\section{References}

1. Castañón-González JA, Camacho-Juárez S, Gorordo-Delsol LA, Garduño-López J, Pérez-Nieto O, Amezcua-Gutiérrez MA, et al. Ventilación mecánica simultánea con un solo ventilador a varios pacientes. Gac Med Mex. 2020;156:250-253.
Gac Med Mex. 2020;156:361

Contents available at PubMed www.gacetamedicademexico.com license (http://creativecommons.org/licenses/by-nc-nd/4.0/). 